\title{
ANTIOKSIDATIVE ACTIVITY OF PUMPKIN OIL CAKE BASED BIOPOLYMER FILMS OBTAINED BY DIFFERENT FILTRATION PROCESS
}

\section{ANTIOKSIDATIVNA AKTIVNOST BIOPOLIMERNIH FILMOVA NA BAZI ULJANE POGAČE TIKVE GOLICE DOBIJENIH RAZLIČITIM POSTUPKOM FILTRACIJE}

\author{
Nevena HROMIŠ, Senka POPOVIĆ, Danijela ŠUPUT, Sandra BULUT, Vera LAZIĆ, Jasmina VITAS, \\ Radomir MALBAŠA, Zdravko ŠUMIĆ, Aleksandra TEPIĆ-HORECKI, Anita VAKULA \\ University of Novi Sad, Faculty of Technology, 21000 Novi Sad, Bulevar cara Lazara 1, Serbia \\ e-mail: nevena.krkic@uns.ac.rs
}

\begin{abstract}
In this work, pumpkin seed oil cake that remains after process of cold pressed oil extraction, was used for the production of composite biopolymer based packaging films. During the production of films, four degrees of filtration were applied. The obtained composite biopolymer films were analyzed for antioxidant activity using three different antioxidant activity assays: the ability to capture free radicals, including ${ }^{\circ} \mathrm{DPPH}$ radical and hydroxyl radical, ${ }^{\circ} \mathrm{OH}$, as well as reduction power assay of the analyzed films.

By comparing the antioxidant activity of the films obtained with different degrees of filtration, it can be concluded that the films obtained by finer filtration (smaller diameter of the filter pore) exhibit greater ability to capture ${ }^{\circ} \mathrm{DP} H \mathrm{H}$ radicals, as well as higher reducing power, while the ability to capture hydroxyl radicals showed different trend. Films obtained from the coarser filtered fractions (higher diameter of the filtrate medium) showed greater ${ }^{\circ} \mathrm{OH}$ scavenging ability.
\end{abstract}

Key words: biopolymer film, pumpkin seed oil cake, filtration degree, antioxidant activity

\section{REZIME}

U ovom radu je za dobijanje biopolimernih ambalažnih filmova korišćena pogača uljane tikve golice, koja zaostaje nakon završene ekstrakcije postupkom hladnog ceđenja ulja. Tokom dobijanja filmova, primenjena su četiri stepena filtracije u cilju dobijanja kompozitnih filmova korišćenjem različitih frakcija, tj. veličine čestica filmogene suspenzije, što može dovesti do većeg prinosa procesa $i$ dodatnog smanjenja količine zaostalog otpada. Dobijeni kompozitni biopolimerni filmovi su analizirani na antioksidativnu aktivnost primenom tri različita, najčešće korišćena, testa za analizu antioksidativne aktivnosti: sposobnost hvatanja slobodnih radikala, među kojima DPPH radikal (kao jedan od najčešće korišćenih testova za ispitivanje antioksidativnog potencijala prirodnih komponenti "in vitro") $i$ hidroksil radikal, $\mathrm{OH}$ (najreaktivniji radikal u biološkim sistemima), kao i određivanje redukcione moći analiziranih filmova. Takođe je ispitan uticaj različitih uslova inkubacije uzorka u reakcionim smešama za ispitivanje antioksidativne aktivnosti.

Poređenjem antioksidativne aktivnosti filmova dobijenih različitim stepenima filtracije, može se zaključiti da filmovi dobijeni finijim filtracijama (manji promer pora filtera) pokazuju veću sposobnost hvatanja 'DPPH radikala, kao i veće vrednosti redukcione moći. Kod sposobnosti hvatanja hidroksil radikala, filmovi dobijeni iz grublje filtriranih frakcija (veći prečnici pora filtracionog medijuma) su pokazali veću antioksidativnu aktivnost. Sa porastom vremena kontakta ispitivanog biofilma u test rastvorima, rasla je antioksidativna aktivnost (za ${ }^{\circ} \mathrm{DPPH}$ test i određivanje redukcione moći). Takođe, tokom testa hvatanja ${ }^{\circ} \mathrm{DPPH}$ radikala, uočeno je da su uzorci filma koji su bili sve vreme kontakta na šejkeru pokazali veću sposobnost hvatanja radikala u odnosu na filmove koji nisu bili podvrgnuti trešenju.

Ključne reči: biopolimerni film, pogača uljane tikve, stepen filtracije, antioksidativna aktivnos.

\section{INTRODUCTION}

Modern consumer requires a responsible attitude towards the environment and this requirement is an integral part of the approach to each product. When food products are concerned, a special attention is given to packaging and the problem of reducing and disposing of packaging waste, which inevitably arises after consuming products (Đević and Dimitrijević, 2010). In this context, biopolymer-based packaging is gaining importance. Natural biopolymers can be used as carriers of active components in order to gradually release them into food during storage, but they can also show active properties that can contribute to packed food safety. Antioxidant properties have been observed in a large number of biopolymer materials based on hydrocolloids (Hromiš et al., 2017).

Packaging based on biopolymers with inherent antioxidant activity is, in addition to its basic product preservation function, active, natural, environmentally friendly and biodegradable and, as such, represents a very interesting subject for investigation in order to develop application for food packaging products (Lazić and Popović, 2015).

Most commonly used assays for testing antioxidant activity of biopolimer films "in vitro" are ${ }^{D} \mathrm{DPH}$ radical assay, ABTS $^{+}$ radical assay and reducing power assay. Apart from these most frequently used tests, hydroxyl radical scavenging capacity test and number or other tests are also present in the literature. The capacity to capture free radicals ('DPPH test) is one of the most commonly used tests to test the antioxidant potential of natural components in vitro. This test indicates that the substance analyzed can capture free radicals, acting as a donor of a hydrogen atom or as an electron donor (Prior et al., 2005; Niramol, 2018). The reducing power assay is often used to evaluate the ability of an antioxidant to donate an electron which is an important mechanism of antioxidant action. Many reports 
have revealed that there is a direct correlation between antioxidant activities and reducing power of certain plant extracts (Irshad et al., 2012; Sakač et al, 2011). Oxidation is the transfer of electrons from one atom to another and represents an essential part of aerobic life. When the electron flow becomes uncoupled, free radicals are generated. Examples of oxygencentered free radicals, known as reactive oxygen species (ROS), include among others (superoxide ${ }^{\circ} \mathrm{O}_{2}^{-}$, peroxyl $\mathrm{ROO}^{\circ}$, alkoxyl $\mathrm{RO}^{\circ}$ and nitric oxide ${ }^{\circ} \mathrm{NO}$ ) hydroxyl radical $\left({ }^{\circ} \mathrm{OH}\right)$, the most reactive radical in biological systems (Gulcin, 2012).

Pumpkin (Cucurbita pepo) is a widely cultivated vegetable in America, Europe, Africa, and Asia, used for human consumption and in traditional medicine (Krimer-Malešević et al., 2011). Pumpkin seeds are rich in proteins, unsaturated fatty acids, phytosterols, and essential minerals like $\mathrm{Zn}, \mathrm{K}, \mathrm{Ca}, \mathrm{Mg}, \mathrm{Fe}, \mathrm{Cu}$, and $\mathrm{P}$. The oil content of pumpkin seeds is about $40-60 \%$, and mostly consists of oleic, palmitic, and stearic acids. Protein content is about $45-46 \%$ in complete seed, and $55-56 \%$ after defatting. Primary use of pumpkin seeds is in pumpkin oil production. After oil have been extracted from the seed, pressed cake remains, rich in proteins and till now this byproduct has been used for animal feeding (Nourmohamadi et al., 2017). Group of authors presented additional approach to pumpkin oil cake valorization by using it for protein or composite biopolymer film production (Popović et al., 2011; Popović et al., 2012)

In this work, pumpkin seed oil cake that remains after process of cold pressed oil extraction, was used for the production of composite biopolymer-based packaging films. During the production of films, four degrees of filtration were applied in order to produce composite films using different fractions, i.e. particle size, which can lead to higher yields of the process and additional reduction in the amount of residual waste. The obtained composite biopolymer films were analyzed for antioxidant activity using three different, most commonly used, antioxidant activity assays: the capacity to capture free radicals, including $\mathrm{DPPH}$ radical (as one of the most commonly used tests for testing antioxidant potential of natural components "in vitro") and hydroxyl radical, $\mathrm{OH}$ (the most active radical in biological systems), as well as determining the reduction power assay of the analyzed films.

\section{MATERIAL AND METHOD}

Grounded hull-less pumpkin (Cucurbita pepo L. c.v. Olinka) oil cake (PuOC) was kindly supplied by „Linum“, Čonoplja, Serbia, and stored at the temperature of $4{ }^{\circ} \mathrm{C}$. All other reagents were of analytical grade.

The film-forming suspension of PuOC (10\%, w/w) was prepared in deionized water, with addition of $30 \% \mathrm{w} / \mathrm{w}$ (per weight of PuOC) glycerol and $0.2 \% \mathrm{w} / \mathrm{w}$ (per weight of polysaccharides in PuOC) guar-xanthan. $\mathrm{pH}$ value of the obtained film forming suspension (FFS) was adjusted to 12.0 using $0.2 \mathrm{M} \mathrm{NaOH}$ and the FFS was incubated at $90^{\circ} \mathrm{C}$, for 20 minutes (Popović et al, 2011). Hot FFS was filtrated through nylon filter with pores around $100 \mu \mathrm{m}$, (PA13XXX, Saati Tech, Milano, Italy) to obtain fine filtration (FF) fraction of FFS, through nylon filter with pores around $140 \mu \mathrm{m}$ PA 9 XXX to obtain intermediate filtration (IF) fraction and through cheesecloth (around $800 \mu \mathrm{m}$, Clearstream Filters Inc., Delhi, Ontario) to obtain rough filtration (RF) fraction of FFS. Fourth fraction was not subjected to filtration and this fraction was labeled NF fraction. Production yield for obtained filtrated FFS were $50 \% \mathrm{w} / \mathrm{w}$ for FF fraction, 80\% for IF fraction, 90-95 \% for GF fraction and $100 \%$ for NF fraction, comparing to total FFS mass. Obtained suspensions were poured onto Teflon coated flat glass surface (350 mm x $500 \mathrm{~mm}$ ) to cast films. Films were air dried for 2 days at room conditions. Dry films were peeled of the glass surface and kept in refrigerated conditions until examination.

DPPH radical scavenging capacity

DPPH radical scavenging capacity of the biopolymer composite films was estimated according to the procedure reported by Morales and Jimenez-Perez (2001), with slight modification. Films were cut in pieces $(10 \times 10) \mathrm{mm}$ and weighed $(0.0176 \pm 0.0031) \mathrm{g}$. Film cuts were then mixed with $4.8 \mathrm{~mL}$ of DPPH ethanolic solution $(80 \mu \mathrm{M})$, and left for two different incubation periods, $3 \mathrm{~h}$ and $24 \mathrm{~h}$ on a shaker, or without using shaker. Absorbance was measured at $520 \mathrm{~nm}$ (JENWAY 6300, $\mathrm{UK}$ ), and the $\mathrm{DPPH}$ radical scavenging activity was calculated by the equation (Eq. 1):

DPPH radical scavenging capacity $=\frac{\text { Ablank }- \text { Asample }}{\text { Ablank }} \times 100$

where Ablank is the absorbance value at $520 \mathrm{~nm}$ of the ethanolic solution of ${ }^{\circ} \mathrm{DPPH}$ without added sample, and Asample is the absorbance value at $520 \mathrm{~nm}$ of the ethanolic solution of DPPH with added sample (film).

Reducing power assay

The determination of reducing power of films was carried out according to Moradi et al. (2012), with slight modification. Films were cut in pieces $(10 \times 10) \mathrm{mm}$ and weighed $(0.0190 \pm$ $0.0024) \mathrm{g}$. Every sample of each film was mixed with $2.5 \mathrm{~mL}$ of phosphate buffer (0.2 M, pH 6.6) and $2.5 \mathrm{~mL}$ of potassium ferricyanide $(1 \%)$. The mixture was incubated at $50{ }^{\circ} \mathrm{C}$ for two different incubation periods, 20 minutes and $3 \mathrm{~h}$. After defined incubation time, $2.5 \mathrm{~mL}$ of trichloroacetic acid (100 g/L) was added to the mixture, which was then centrifuged at $3000 \mathrm{rpm}$, for $10 \mathrm{~min}$. The obtained supernatant $(2.5 \mathrm{~mL})$ was mixed with $2.5 \mathrm{~mL}$ of distilled water and $0.5 \mathrm{~mL}$ of $\mathrm{FeCl}_{3}(1 \mathrm{~g} / \mathrm{L})$ and the absorbance was measured at $700 \mathrm{~nm}$ (JENWAY 6300, UK). The increase of the absorbance of the reaction mixture indicates increase of the reducing power against ferric ions.

Hydroxyl radical scavenging activity

Hydroxyl radical scavenging activity was carried out according to Deeseenthum and Pejovic (2010), with slight modification. Films were cut in pieces $(5 \times 5) \mathrm{mm}$ and weighed $(0.0111 \pm 0.0009) \mathrm{g}$. Every film sample was mixed with $0.9 \mathrm{~mL}$ of sodium phosphate buffer $(0.2 \mathrm{M}, \mathrm{pH}=7), 0.3 \mathrm{~mL}$ of 2deoxyribose $(10 \mathrm{mM}), 0.3 \mathrm{~mL}$ of EDTA $(10 \mathrm{mM}), 0.3 \mathrm{~mL}$ of FeSO4 $(10 \mathrm{mM}), 0.3 \mathrm{~mL}$ of hydrogen peroxide $(10 \mathrm{mM})$ and 1 $\mathrm{mL}$ of distilled water. Samples were than incubated at three different incubation periods, $1 \mathrm{~h}, 3 \mathrm{~h}$ and $24 \mathrm{~h}$ at $37^{\circ} \mathrm{C}$. After incubation period, $1.5 \mathrm{~mL}$ of trichloroacetic acid (2.8\%) and thiobarbituric acid $(0.1 \%)$ was added and samples were kept in boiled water for $10 \mathrm{~min}$. After cooling, samples were centrifuged at $3000 \mathrm{rpm}$ for $10 \mathrm{~min}$. The absorbance of each sample was measured at $520 \mathrm{~nm}$ (JENWAY 6300, UK). The antioxidant activity was calculated based on the following equation (Eq. 2):

Hydroxyl radical scavenging activity $=\frac{\text { Ablank }- \text { Asample }}{\text { Ablank }} \times 100$

where Ablank is the absorbance value at $520 \mathrm{~nm}$ of the reaction solution without sample (film) and Asample is the absorbance value at $520 \mathrm{~nm}$ of the reaction solution with sample (film).

Statistical analysis

All determinations were made in triplicate. Statistical analysis was carried out using OriginPro 8. All data were presented as mean value with their standard deviation indicated 
(mean $\pm \mathrm{SD}$ ). Variance analysis (ANOVA) was performed, with a confidence interval of $95 \%(\mathrm{p}<0.05)$. Means were compared by the Tukey test.

\section{RESULTS AND DISCUSSION}

DPPH radical scavenging capacity of tested films is shown in Graph1. Based on obtained and presented results, it can be seen that different factors affect scavenging capacity of films. For all analyzed films, time of test duration, i.e. free radical and biopolymer film contact time, had significant influence on test results. With prolonged contact time, scavenging capacity increases $(p<0.05)$. Second factor that affected test results was that some samples were placed on the shaker during incubation (contact) time, while other samples were not shaken. Dynamic contact conditions (using shaker) also led to higher results for scavenging capacity, especially in combination with prolonged time of contact $(\mathrm{p}<0.05)$. Prolonged time of contact, as well as dynamic contact conditions, probably lead to release of low molecular weight active compounds with scavenging capacity that are present in the matrixes of produced composite films. These compounds might be of different chemical origin, some of them being: present amino acids (Pires, 2011); peptides and protein hydrolysates of low molecular weight (Vaštag et al., 2010; Vaštag et al., 2011; Popović, 2010) phenolic acids (Peričin et al.,2009), antioxidants present in pumpkin seed oil (Murković, 2009), acrylamide from Maillard's reaction between the carbonyl group of reducing sugars and nucleophilic amino groups of amino acids of the protein (Thomas and Forbes, 2010) and other components with antioxidant activity (Xanthopoulou, 2009).

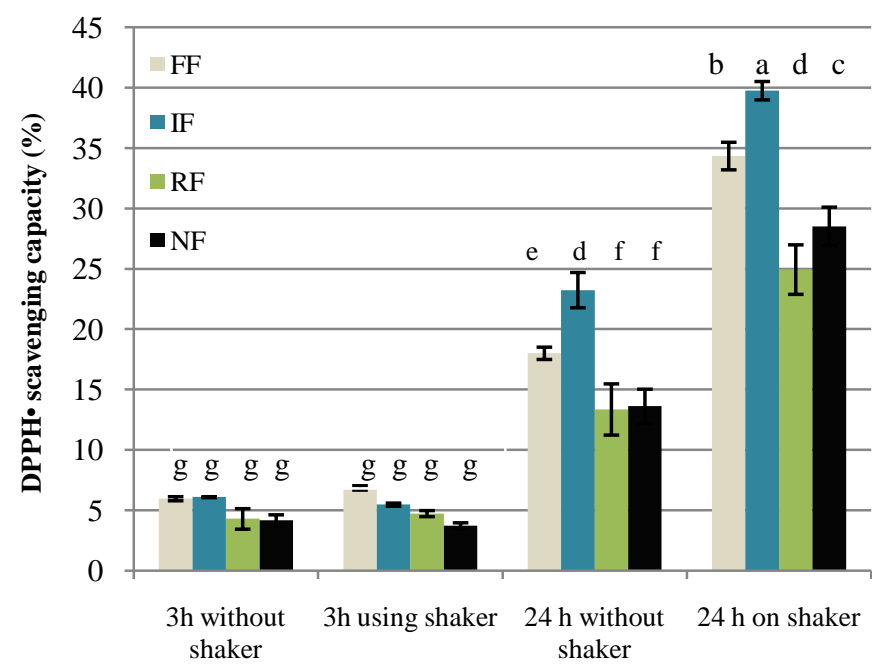

Incubation time and conditions

\section{${ }_{a, b, c, d, e, f, g}$ Different letters denote significantly different means with $95 \%$ probability $(p<0.05)$}

Fig 1. 'DPPH scavenging capacity of analyzed films after different incubation time and conditions

When films obtained by different filtration process are analyzed and compared, it can be seen that finer filtrated films (FF and IF) showed higher scavenging capacity, compared to RF and NF films. This might be due to additional compounds present in both RF and NF films, which fill film matrix and promote formation of additional intermolecular bonds and cross link long biopolymer chains, preventing in this way release of low molecular bioactive compounds. This effect is more pronounced after $24 \mathrm{~h}$ incubation time in DPPH solution $(p<0,05)$. Scavenging capacity of pumpkin oil cake protein isolate films was reported in the literature to be 0.030 to over 0.9 $\mathrm{EC}_{50}$ value for ${ }^{\mathrm{ABTS}^{+}}$radical cation scavenging capacity. For composite films obtained from pumpkin oil cake, ${ }^{\circ B T S}{ }^{+}$ radical cation scavenging capacity was about $20 \%$ to about 70 $\%$, depending on film preparation conditions. For composite films gelatin-pumpkin oil cake, 'DPPH scavenging capacity was $15 \%$ to over $25 \%$, depending on the compound ratio (Popović, 2013). The DPPH radical-scavenging capacity of fish protein films was reported to amount $15 \%$ to $30 \%{ }^{\circ} \mathrm{DPPH}$ scavenging capacity and determined activity was attributed to the presence of free sulfhydryl groups and other aminoacids such as Tryptophan, Methionine and Tyrosine (Pires et al., 2011; Pires et al., 2013)

Due to the large number of reactive chemical species that impair the quality of lipids in food and the variety of mechanisms of their action, it is impossible to define a unique measure of antioxidant activity. In the process of evaluating the antioxidant potential of the test substance, it is necessary to choose a combination of several tests based on different principles and show the antioxidant potential of the test substance through various mechanisms of action (Lesjak, 2011).

Along with DPPH radical scavenging capacity, pumpkin oil cake films were tested for their reducing power and obtained results are shown in Graph 2. It can be seen from Graph 2 that test results were affected by experimental conditions, similar to the DPPH test. With increasing incubation time, from 20 minutes to $3 \mathrm{~h}$, reducing power was increased for all samples, except for RF films. This is probably due to changes that film undergoes during incubation at $50{ }^{\circ} \mathrm{C}$ in incubation solution, most probably leading to dissolution of low molecular weight active compounds, as well as loosening film matrix and making active groups available. Also, these conditions might have affected partial thermal hydrolytic changes in polymer chains incorporated in the film structure. When films obtained by different filtration process are compared, similar relation can be observed after different test incubation time: highest reducing power was found for FF and lowest for RF. IF and NF films had values in between. Observed difference was significant $(p<0.05)$ after 3 h, while after 20 minutes of incubation, observed differences were not significant $(\mathrm{p}<0.05)$

Strong reducing power of the protein hydrolysates could be a result of the increase in availability of hydrogen ions (protons and electrons) due to cleavage of the peptide bonds. Proton donation could occur at specific side-chain groups or specific peptide structures (Sbrogio, 2016). Different authors suggested correlation between antioxidant activity of proteins and their amino acid compositions (Nourmohammadi et al., 2017). Sbrogio et al. (2016) highlights that this property of the amino acid residues is limited by their tertiary structure, because many amino acids with antioxidant potential can be buried within the protein core, where they are inaccessible to pro-oxidants. Additionally, a positive relationship between sulphur-containing amino acid, acidic and hydrophobic amino acids or amino acids with aromatic side chains (tryptophan, tyrosine and phenylalanine) with ferric ion reducing ability was reported (Venuste et al., 2013; Sbroggio, 2016). In addition to reducing power originating from proteins, peptides and amino acids, tested films also include numerous active species that might have contributed to resulting reducing power of the films. Most of these active compounds are similar to the active compounds responsible for the DPPH scavenging capacity. This is probably why reducing power of tested films is higher compared to hydrolysates obtained by enzymatic hydrolysis of pumpkin oil 
cake protein isolates (Vaštag et al., 2010; Vaštag et al., 2011; Popović, 2010).

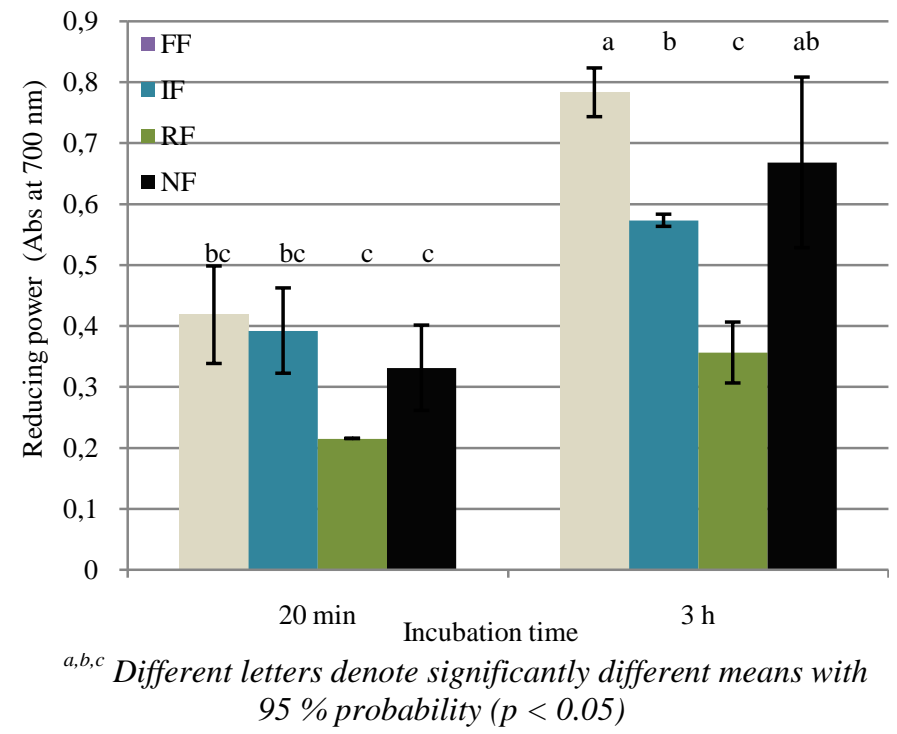

Fig. 1. Reducing power assay for analyzed films after different incubation time

In addition to the technical simplicity of ${ }^{\circ} \mathrm{DPPH}$ assay, it should be mentioned that this assay was shown to have limitations in measuring radical scavenging capacity of an antioxidant in food. Sole mechanism of radical reactions differs for the ${ }^{\circ} \mathrm{DPPH}$. Instead of hydrogen atom transfer reaction present in reactions between antioxidants and peroxyl radicals, DPPH was shown to be involved in electron transfer reaction, with hydrogen atom abstraction being marginal reaction path. Also, DPPH is a long-lived nitrogen radical, while lipid peroxidation in food implies highly reactive and transient peroxyl radicals (Huang et al., 2005). Therefore, testing of radical scavenging capacity for analyzed films was supplemented with hydroxyl radical scavenging capacity, showed in Graph 3. Biologically, the hydroxyl radical is produced in Fenton reaction, where hydrogen peroxide reacts with $\mathrm{Fe}(\mathrm{II})$ or other less reactive ions, like such as $\mathrm{Cu}^{+}, \mathrm{Ti}^{3+}, \mathrm{Cr}^{2+}$ and $\mathrm{Co}^{2+}$ (Gülçin, 2012). Formed hydroxyl radical is an extremely reactive and short-lived specie that can hydroxylate DNA, proteins, and lipids.

As shown in Graph 3., after 1h incubation time, analyzed films showed scavenging capacity from around $30 \%$ for FF and IF films to about $60 \%$ for NF film. After $3 \mathrm{~h}$ incubation time, scavenging capacity was $10 \%$ for the FF film, $16 \%$ for the IF film and around $40 \%$ for GF and NF films. Higher values for scavenging capacity towards ${ }^{\circ} \mathrm{OH}$ for shorter film incubation time, compared to ${ }^{\circ} \mathrm{DPH}$ may be attributed to higher reactivity of hydroxyl radical. Comparing results to the results for ${ }^{\circ} \mathrm{DPPH}$ scavenging capacity, as well as reducing power of analyzed films, it can be seen that results for ${ }^{\circ} \mathrm{OH}$ scavenging capacity differ, because with prolonged incubation time of sample in reaction mixture, scavenging capacity decreases for all analyzed films. This difference might be explained by increasing reducing power of film during incubation time. Namely, it was shown that antioxidants in food (such as vitamin C) may act as pro-oxidants by reducing $\mathrm{Fe}(\mathrm{III})$ to $\mathrm{Fe}(\mathrm{II})$ and make the ${ }^{\circ} \mathrm{OH}$ generation catalytic (Huang et al., 2015). It is possible that during prolonged incubation time low molecular weight substances mentioned above, with higher reducing power are dissolved and freed from film matrix leading to the pro-oxidant effect with ${ }^{\circ} \mathrm{OH}$ generation. This dissolution is easier in FF and IF films, due to less dense film matrix, and this might be correlated to more pronounced mentioned pro-oxidant effect for these films.

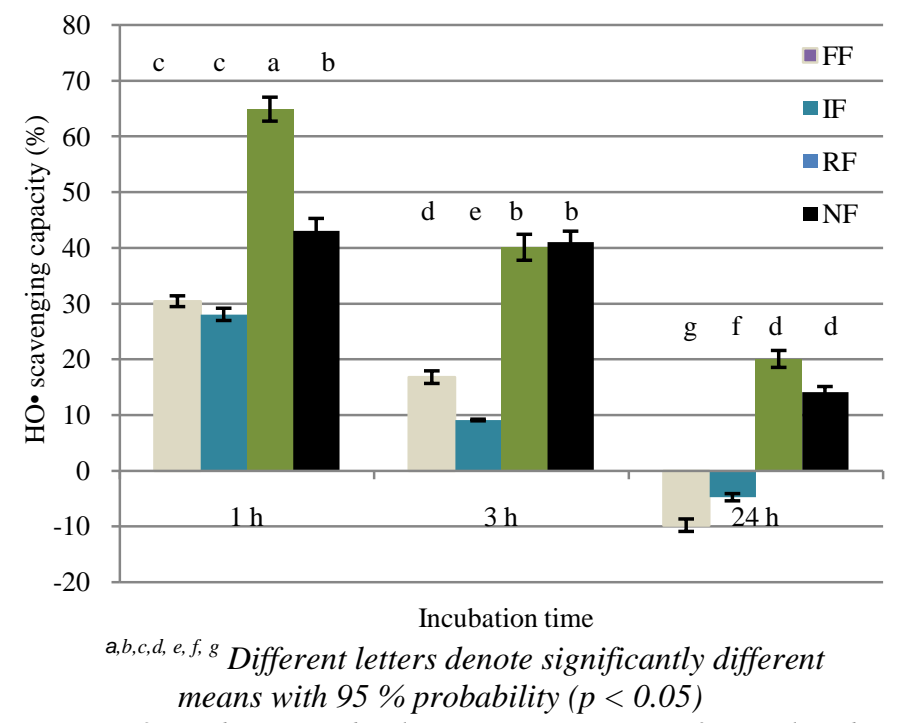

Fig. 2. Hydrogen radical scavenging capacity for analyzed films after different incubation time

\section{CONCLUSION}

Films based on pumpkin oil cake showed low to intermediate antioxidant activity, based on ${ }^{\circ} \mathrm{DPPH}$ and ${ }^{\circ} \mathrm{OH}$ scavenging assays, with good reducing power. Antioxidant activity was shown to be influenced by film incubation time (films start to swell and partially dissolve in reaction mixtures). ${ }^{\circ} \mathrm{DPPH}$ scavenging capacity, as well as reducing power was increased with increasing incubation time, while ${ }^{\circ} \mathrm{OH}$ scavenging capacity decreased as the incubation time was prolonged. If films produced by different filtration technique are compared, differences between obtained films are significant. These differences are, most probably, due to availability of low molecular weight active compounds, as well as protein and other following biopolymers active groups availability. Since it was shown that test conditions highly affect results for antioxidant activity of tested films "in vitro", it would be interesting to test effectiveness of these films "in vivo", in real food system, where films would be tested as active food packaging.

ACKNOWLEDGEMENT: This study was supported by the Ministry of Education, Science and Technological Development of the Republic of Serbia, Project No. TR31032: Development of production technology of traditional fermented dry sausages with geographical origin to obtain safe products of standard quality (2011-).

\section{REFERENCES}

Đević, M., Dimitrijević, Aleksandra (2010). Technology of food packaging. Journal on Processing and Energy in Agriculture, 14 (2), 72-75.

Hromiš, Nevena, Lazić, Vera, Popović, Senka, Šuput, Danijela, Bulut, Sandra (2017). Antioxidative activity of chitosan and chitosan based biopolymer film. Food and Feed Research, 44 (2), 91-100.

Lazić, Vera, Popović, Senka (2015). Biorazgradivi ambalažni materijali. Tehnološki fakultet, Novi Sad, Serbia

Niramol, P. (2018). Bioactive compounds and antioxidant activity of wines from different currant cultivars. Journal on Processing and Energy in Agriculture, 22 (1), 27-30.

Sakač, Marijana, Sedej, Ivana, Mandić, Anamarija, Mišan, Aleksandra (2011). Wheat and buckwheat milling fractions: 
Insight in their functional characteristics. Journal on Processing and Energy in Agriculture, 15 (3), 173-178.

Prior, R., Wu, Xianli, Schaich, Karen (2005). Standardized Methods for the Determination of Antioxidant Capacity and Phenolics in Foods and Dietary Supplements. Agricultural and Food Chemistry, 53, 4290-4302.

Irshad, M, Zafaryab, M., Singh, M., Rizvi, M. M.A. Comparative Analysis of the Antioxidant Activity of Cassia fistula Extracts. International Journal of Medicinal Chemistry, 2012, Article ID 157125, 6 pages

Gülçin, Ì (2012). Antioxidant activity of food constituents: an overview. Archives of Toxicology, 86 (3), 345-391.

Krimer-Malešević, Vera, Mađarev-Popović, Senka, Vaštag,Žužana, Radulović, Ljiljana, Peričin, Draginja (2011). Phenolic Acids in Pumpkin Seed in Nuts \& Seeds in Health and Disease Prevention, PART 2. Effects of Specific Nuts and Seeds. Eds. Preedy, ¡V., Watson, R., Patel, V., Elsevier Inc.

Nourmohammadi, E., SadeghiMahoonak, Alireza, Alami, M., Ghorbani, M. (2017). Amino acid composition and antioxidative properties of hydrolysed pumpkin (Cucurbita pepo L.) oil cake protein. International journal of food properties, 20 (12), 3244-3255.

Popović, Senka (2013). Istraživanje dobijanja i karakterizacija biorazgradivih kompozitnih filmova na bazi biljnih proteina. Doktorska teza, Tehnološki fakultet, Novi Sad,Srbija.

Popović, Senka, Peričin, Draginja, Vaštag, Žužana, Popović, Ljiljana, Lazić, Vera (2011). Evaluation of edible film-forming ability of pumpkin oil cake; effect of $\mathrm{pH}$ and temperature. Food Hydrocolloids, 25 (3) 470-476.

Popović, Senka, Peričin, Draginja, Vaštag, Žužana, Lazić, Vera, Popović, Ljiljana (2012). Pumpkin oil cake protein isolate films as potential gas barrier coating. Journal of Food Engineering 110 (3), 374-379.

Morales, F.J., Jimenez-Perez, S. (2001). Free radical scavenging capacity of Maillard reaction products as related to colour and fluorescence. Food Chemistry, 72 (1), 119-125.

Moradi, M., Tajik, H., Rohani, S. M. R., Oromiehie, A. R., Malekinejad, H., Aliakbarlu, J., Hadian, M. (2012). Characterization of antioxidant chitosan film incorporated with Zataria multiflora Boiss essential oil and grape seed extract. LWT - Food Science and Technology, 46 (2), 477-484.

Deeseenthum, S., Pejovic Jelena (2010). Bacterial Inhibition and Antioxidant Activity of Kefir Produced from Thai Jasmine Rice Milk. Biotechnology 9 (3), 332-337.

OriginPro 8 SR2 (Scientific graphing and data ana-lysis software) (2001). v.8.0891(B891)., OriginLab Corporation, Northampton, MA, USA (https://www.originlab.com).

Pires, C., Ramos, C., Teixeira, G., Batista, I., Mendes, R., Nunes, L., Marques, A. (2011). Characterization of biodegradable films prepared with hake proteins and thyme oil. Journal of Food Engineering 105 (3), 422-428.

Vaštag,Žužana, Popović, Ljiljana, Popović, Senka, KrimerMalešević, Vera, Peričin, Draginja (2010). Hydrolysis of pumpkin oil cake protein isolate and free radical scavenging activity of hydrolysates: Influence of temperature, enzyme/substrate ratio and time. Food and bioproducts processing, 88 (2-3), 277-282.

Vaštag,Žužana, Popović, Ljiljana, Popović, Senka, KrimerMalešević, Vera, Peričin, Draginja (2011). Production of enzymatic hydrolysates with antioxidant and angiotensin-I converting enzyme inhibitory activity from pumpkin oil cake protein isolate. Food Chemistry, 124 (4), 1316-1321.

Vaštag,Žužana (2010). Characterization of bioactive protein products obtained by enzymatic modifications of pumpkin oil cake protein isolate. Special Abstracts / Journal of Biotechnology 150S, S1-S576, S304.

Popović, Ljiljana (2010). Hydrolysis of pumpkin oil cake globulin-cucurbitin by pepsin; Antioxidant and functional properties of resulting hydrolysates. Special Abstracts / Journal of Biotechnology 150S, S1-S576, S315.

Peričin, Draginja Krimer-Malešević, Vera, Trivić, Svetlana, Radulović, Ljiljana (2009). The distribution of phenolic acids in pumpkin's hull-less seed, skin, oil cake meal, dehulled kernel and hull. Food Chemistry 113 (2), 450-456.

Murkovic, M. (2009). Pumpkin Seed Oil in Gourmet and Health-Promoting Specialty Oils, EDS. Moreau, R., KamalEldin, A., Academic Press and AOCS Press, 345-358.

Thomas, M.C., Forbes, J. (2010). The Maillard Reaction: Interface Between Aging, Nutrition and Metabolism. Royal Society of Chemistry, Cambridge.

Pires, C., Ramos, C., Teixeira, B., Batista, I., Mendes, R., Nunes, L., Marques, A. Hake proteins edible films incorporated with essential oils: Physical, mechanical, antioxidant and antibacterial properties. Food Hydrocolloids, 30 (1), 224-231.

Xanthopoulou, Marianna, Nomikos, T., Fragopoulou, Elizabeth, Antonopoulou, S. (2009). Antioxidant and lipoxygenase inhibitory activities of pumpkin seed extracts. Food Research International 42 (5-6), 641-646.

Lesjak, M. (2011). Biopotencijal i hemijska karakterizacija ekstrakata i etarskih ulja vrsta roda Juniperus L. (Cupressaceae). Doktorska disertacija, Prirodno-matematički fakultet, Univerzitet u Novom Sadu, Srbija.

Sbroggio, Melissa Ferreira, Montilha, Marina Silveira, De Figueiredo, Vitória Ribeiro Garcia, Georgetti, Sandra Regina, Kurozawa, L.E. (2016). Influence of the degree of hydrolysis and type of enzyme on antioxidant activity of okara protein hydrolysates Food Science and Technology, Campinas, 36(2), 375-381.

Venuste, M., Zhang, X., Shoemaker, C., Karangwa, E., Abbas, S., Kamdem, P.E. (2013). Influence of enzymatic hydrolysis and enzyme type on the nutritional and antioxidant properties of pumpkin meal hydrolysates. Food and Function, 4, 811820.

Huang, D., Ou, B., Prior, R. (2005). The Chemistry behind Antioxidant Capacity Assays. Journal of Agricultural and Food Chemistry, 53 (6), 1841-1856

Received: 19. 02. 2019.

Accepted: 20. 03. 2019. 